\title{
Aging Decreases L-Type Calcium Channel Currents and Pacemaker Firing Fidelity in Substantia Nigra Dopamine Neurons
}

\author{
Sarah Y. Branch, ${ }^{1}$ Ramaswamy Sharma, ${ }^{2}$ and Michael J. Beckstead ${ }^{1,3}$ \\ ${ }^{1}$ Department of Physiology, ${ }^{2}$ Department of Cellular and Structural Biology, and ${ }^{3}$ Center for Biomedical Neuroscience, University of Texas Health Science \\ Center, San Antonio, Texas 78229
}

\begin{abstract}
Substantia nigra dopamine neurons are involved in behavioral processes that include cognition, reward learning, and voluntary movement. Selective deterioration of these neurons is responsible for the motor deficits associated with Parkinson's disease (PD). Aging is the leading risk factor for PD, suggesting that adaptations occurring in dopamine neurons during normal aging may predispose individuals to the development of PD. Previous studies suggest that the unique set of ion conductances that drive spontaneous, rhythmic firing of action potentials could predispose substantia nigra dopamine neurons to selective neurodegeneration. Here we show, using patch-clamp electrophysiological recordings in brain slices, that substantia nigra dopamine neurons from mice 25-30 months of age (old) have comparable membrane capacitance and input resistance to neurons from mice 2-7 months of age (young). However, neurons from old mice exhibit slower firing rates, narrower spike widths, and more variable interspike intervals compared with neurons from young mice. Dopamine neurons from old mice also exhibit smaller L-type calcium channel currents, providing a plausible mechanism that likely contributes to the changes in impulse activity. Age-related decrements in the physiological function of dopamine neurons could contribute to the decrease in voluntary movement and other dopamine-mediated behaviors observed in aging populations. Furthermore, as pharmacological antagonism of L-type calcium channels has been proposed as a potential treatment for the early stages of PD, our results could point to a limited temporal window of opportunity for this therapeutic intervention.
\end{abstract}

Key words: dopamine; firing; L-type calcium channels; mouse; pacemaking

\section{Introduction}

Dopamine (DA) neurons of the substantia nigra contribute to behaviors that include voluntary movement, sequence learning, and feeding (Hnasko et al., 2006; Jin and Costa, 2010). Mass degeneration of these neurons is a hallmark sign of Parkinson's disease (PD) and is responsible for the motor symptoms of the disease (Hornykiewicz, 1975). Aging is the leading risk factor for the development of PD, and some behavioral symptoms, including bradykinesia and cognitive decline, are common to both aging and PD. Unfortunately, little is cur-

\footnotetext{
Received 0ct. 1, 2013; revised May 30, 2014; accepted June 5, 2014.

Author contributions: S.Y.B. and M.J.B. designed research; S.Y.B., R.S., and M.J.B. performed research; S.Y.B., R.S., and M.J.B. analyzed data; S.Y.B., R.S., and M.J.B. wrote the paper.

This work was supported by a Nathan Shock Pilot Award P30 AG013319 and R01 DA32701 to M.J.B. through the National Institutes of Health, as well as a Center for Biomedical Neuroscience/Institute for Integration of Medicine \& Science Pilot Award. The authors thank Dr. Amanda Sharpe for her contribution towards the development of the transcardial perfusion protocol, Dr. luliia Polina for preliminary work on the project, and Frida Teran for technical support.

The authors declare no competing financial interests.

Correspondence should be addressed to Dr. Michael J. Beckstead, University of Texas Health Science Center-San Antonio, Department of Physiology, MSC 8253, 7703 Floyd Curl Drive, San Antonio, TX 78229. E-mail: beckstead@uthscsa.edu.

DOI:10.1523/JNEUROSCI.4228-13.2014

Copyright $\odot 2014$ the authors $\quad 0270-6474 / 14 / 349310-09 \$ 15.00 / 0$
}

rently known about how advancing age affects specific ion conductances responsible for DA neuron function.

DA neurons are autonomous pacemakers that fire action potentials in the absence of excitatory synaptic input (Surmeier et al., 2005). Several intrinsic conductances that are active at subthreshold potentials contribute to this tonic firing, including a persistent sodium current, L-type calcium currents, and the hyperpolarization-activated cation current $\mathrm{I}_{\mathrm{H}}$ (Neuhoff et al., 2002; Puopolo et al., 2007; Putzier et al., 2009). Conversely, small conductance calcium-activated potassium (SK) channels and A-type potassium channels tend to slow and/or affect the regularity of pacemaker firing (Shepard and Bunney, 1991; Liss et al., 2001; Wolfart et al., 2001; Wolfart and Roeper, 2002; Hahn et al., 2003, 2006; Khaliq and Bean, 2008). DA neurons in the substantia nigra become more dependent on calcium channels to drive tonic firing as animals progress from adolescence into adulthood (Chan et al., 2007), and increased calcium handling could predispose nigral neurons to oxidative damage (Guzman et al., 2010). This has produced speculation that L-type calcium channel antagonists commonly used as antihypertensives could also be beneficial therapeutics during early stages of PD.

Little is currently known about how advancing age affects specific ion conductances responsible for DA neuron impulse activity. Because of the challenging nature of patch-clamp re- 
cordings in brain slices from old mice, an electrophysiological analysis of individual conductances in DA neurons from old mice has not been reported. Measures such as transcardial perfusion of a chilled solution are sometimes used to improve the viability of neurons in slice preparations (Chen et al., 2008; Dryanovski et al., 2013), but this has not been used to study DA neurons in slices from rodents that are approaching their life expectancy. Thus, it is not known how intrinsic conductances are altered in DA neurons from extremely old animals and how this could affect tonic firing.

To address this issue, we optimized our brain slicing procedure to enable recordings of DA neurons from mice very near to their life expectancy (25-30 months) and from young adult mice (2-7 months). Remarkably, most of the electrophysiological parameters we measured were unaffected by aging. However, pacemaker firing rate and fidelity were significantly impaired in neurons from old mice. Although most intrinsic conductances that we tested were unaffected by age, we did observe dramatically smaller L-type calcium channel currents in intact neurons from old mice. Because L-type calcium channel antagonists have been posited as a possible treatment for PD, our findings could suggest a limited time window for the efficacy of this therapeutic intervention.

\section{Materials and Methods}

Brain slice electrophysiology. Young (2-7 months) and old (25-30 months) male C57BL6J mice were obtained from the National Institute on Aging aged rodent colony and group housed under a 14:10 light cycle with free access to food and water. Old mice were on average slightly larger and a subset that were measured had a mean weight of $31.8 \pm 1.1 \mathrm{~g}$ versus $28.8 \pm 0.71 \mathrm{~g}$ for young mice, weighed just before death $(n=7)$. On the day of recording, mice were anesthetized with 2,2,2tribromoethanol (300-500 mg/kg) and perfused transcardially for $1 \mathrm{~min}$ with oxygenated, ice-cold physiological aCSF containing the following (in mM): $126 \mathrm{NaCl}, 2.5 \mathrm{KCl}, 1.2 \mathrm{MgCl}_{2}, 2.4 \mathrm{CaCl}_{2}, 1.4 \mathrm{NaH}_{2} \mathrm{PO}_{4}, 25$ $\mathrm{NaHCO}_{3}, 11$ D-glucose, and 1.25 kynurenic acid. Brains were extracted, blocked, and mounted on a vibrating microtome (Leica Microsystems). Horizontal slices (190-200 $\mu \mathrm{m}$ thick) of the ventral mesencephalon containing the substantia nigra were collected and thereafter maintained before recording at $34^{\circ} \mathrm{C}$ in aCSF plus the NMDA receptor antagonist MK-801 (10 $\mu \mathrm{M})$, continuously bubbled with $95 \% \mathrm{O}_{2} / 5 \% \mathrm{CO}_{2}$. Recordings were performed at $34^{\circ} \mathrm{C}$ under continual perfusion of aCSF at a flow rate of $2 \mathrm{ml} / \mathrm{min}$.

Putative dopamine neurons in the substantia nigra pars compacta were first identified visually as the large neurons very near (but not directly lateral to) the medial terminal nucleus of the accessory optic tract. They were further classified electrophysiologically by their spontaneous, slow firing $(<5 \mathrm{~Hz})$ of wide extracellular waveforms, membrane capacitance of $>20 \mathrm{pF}$, input resistance in the low $\mathrm{M} \Omega$ range, and by an $\mathrm{I}_{\mathrm{H}}$ current $>100$ pA (Ford et al., 2006; Branch and Beckstead, 2012). Pipettes of $9-10 \mathrm{M} \Omega$ resistance filled with a Na HEPES-based solution (plus $20 \mathrm{~mm} \mathrm{NaCl}, 290 \mathrm{mOsm} / \mathrm{L}, \mathrm{pH}$ 7.40) were used for extracellular recordings using the loose cell attached method as previously described (Branch and Beckstead, 2012). Whole-cell patch recordings were made with $1.8-$ $2.0 \mathrm{M} \Omega$ resistance pipettes filled with internal solution (in $\mathrm{mm}$ ) as follows: $115 \mathrm{~K}$-methylsulfate or cesium chloride, $20 \mathrm{NaCl}, 1.5 \mathrm{MgCl}_{2}, 10 \mathrm{HEPES}$, 0.025 EGTA, 2 ATP, and 0.4 GTP, pH 7.35-7.40, 267-275 mOsm/L. The experiments described in Figure 4 included the addition of neurotransmitter receptor antagonists to the aCSF: picrotoxin $\left(100 \mu \mathrm{M}, \mathrm{GABA}_{\mathrm{A}}\right)$, CGP55845 (100 nM, GABA ${ }_{\mathrm{B}}$ ), DNQX (10 $\left.\mu \mathrm{M}, \mathrm{AMPA}\right)$, and hexamethonium $(100 \mu \mathrm{M}, \mathrm{nACh}-\mathrm{R})$. Blockers used at various times to isolate ionic conductances included apamin (100 nM, SK channels), tetrodotoxin (TTX, $500 \mathrm{~nm}$, voltage-gated Na channels), tetraethylammonium (TEA, $1 \mathrm{~mm}, \mathrm{~K}$ channels), and nimodipine ( $3 \mu \mathrm{M}$, L-type Ca channels). Liquid junction potentials were measured and corrected using the method described by Neher (1992).
Data were acquired at $50 \mathrm{kHz}$ and filtered at $6 \mathrm{kHz}$ using a Multiclamp 700B amplifier (Molecular Devices). Data were recorded and later analyzed offline using Axograph X software (www.axograph.com). Voltage ramps were resampled at $0.014 \mathrm{kHz}$ ( $1 \mathrm{mV}$ increments) for analysis.

$R N A$ extraction and real-time quantitative PCR. Dissected substantia nigra from young $(n=7)$ and old $(n=4$ or 5$)$ mice were stored in RNAlater (QIAGEN) at $-80^{\circ} \mathrm{C}$. After homogenization using TissueMiser (Fisher Scientific), RNA was extracted using RNeasy mini Plus kit (QIAGEN) as per the manufacturer's instructions. Concentration was quantified (Nanodrop Products) and sample quality verified based on 260/280 ratio. RNA was converted to cDNA using qScript (Quanta Biosciences). Expression levels were analyzed on an AB 7900 Real Time PCR System (Invitrogen) using SYBR Select Master Mix (Invitrogen). Cycle conditions were as follows: $95^{\circ} \mathrm{C}$ for $15 \mathrm{~s}, 60^{\circ} \mathrm{C}$ for $1 \mathrm{~min}$. Target gene expression levels were normalized to expression of the endogenous reference control gene, eEF1 $\alpha 1$. All reactions were performed in triplicates with standard curves for each primer set and analyzed using the Relative Expression Software Tool (Pfaffl et al., 2002). The presence of single PCR products was confirmed based on dissociation curves and by separation on agarose gels (data not shown). PCR was performed using the following primers (forward followed by reverse): Scn1a: 5'-TCAGAGGGAAGCACAGTAGAC-3' and 5'-TTCCACGCTGATTTGACAGCA-3'; Scn2a: 5'-ATTTTCGGCTCATTCTTCACACT-3' and 5'-GGGCGAGGTATCGGTTTTTGT-3'; Scn5a: 5'-AT GGCAAACTTCCTGTTACCTC- $3^{\prime}$ and $5^{\prime}$-CCACGGGCTTGTTTTTCAGC$3^{\prime}$; Scn $1 b: 5^{\prime}$-GGATTCCGATACCGAGGCTG-3' and 5'-GGTCCACTCCGTGAAGGTTT-3'; Scn $2 b$ : 5'-AGTAAGTACGACGTGTCAGTGA-3' and 5'-AGGGTTGGTAATGTAGCAGTTG-3'; Scn3b: 5'-ATGTGTCCAGG GAGTTTGAGT-3' and 5'-TTCGGCCTTAGAGACCTTTCT-3'; Hcn1: $5^{\prime}$ -

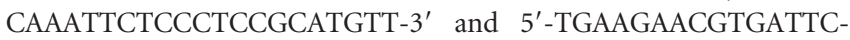
CAACTGG-3'; Kcnn3: 5'-TGTTGCACTCTTCTCCCACG-3' and 5'-GGTCATTGAGATTTAGCTGGCT-3'; Cacnalc: 5'-ATGAAAACA CGAGGATGTACGTT-3' and 5'-ACTGACGGTAGAGATGGTTGC-3'; Cacnald: 5'-AGAGGACCATGCGAACGAG-3' and 5'-CCTTCACCAGAAATAGGGAGTCT-3'; eEf1 $\alpha 1$ : 5'-ATTCCGGCAAGTCCACCACAA-3' and 5'-CATCTCAGCAGCCTCCTTCTCAAAC-3'.

Immunohistochemistry. Dopamine cells of the substantia nigra were patch-clamped with pipettes $(2 \mathrm{M} \Omega)$ filled with an internal solution containing $0.2 \%$ neurobiotin (Vector Laboratories). After electrophysiological recordings, brain slices were postfixed in 4\% PFA overnight and then transferred to a KPBS solution until processed. Initially slices were bathed in a $1 \% \mathrm{H}_{2} \mathrm{O}_{2}$ solution for $15 \mathrm{~min}$, washed and blocked with $5 \%$ goat serum and $0.3 \%$ Triton X-100 (Sigma-Aldrich) for $1 \mathrm{~h}$. After washing with KPBS, slices were then incubated for at least $48 \mathrm{~h}$ in anti-tyrosine hydroxylase (final dilution 1:250; EMD Millipore) at $4^{\circ} \mathrm{C}$. After washing with KPBS, the slices were exposed to the goat anti-rabbit AlexaFluor594 (final dilution 1:750; Abcam) for $2 \mathrm{~h}$. A conjugated streptavidin AlexaFluor-488 antibody (final dilution 1:750; Jackson ImmunoResearch Laboratories) was added to the secondary antibody solution for an additional hour. After sufficient washes in K-phosphate buffered saline, the slices were mounted on gelatin-coated slides and the slides were coverslipped using Prolong Gold antifade reagent (Invitrogen). Images were collected on an Olympus DP72 microscope using Olympus standard cellSens software.

Drugs. DNQX, picrotoxin, MK-801, kynurenic acid, hexamethonium chloride, guanosine $5^{\prime}$ triphosphate sodium salt hydrate (GTP), adenosine $5^{\prime}$ triphosphate magnesium salt (ATP), EGTA, cesium chloride, TTX, TEA, 2,2,2-tribromoethanol, cadmium chloride, and goat serum were purchased from Sigma-Aldrich. CGP 55845 hydrochloride and nimodipine were purchased from Tocris Bioscience. Apamin was obtained from Fisher Scientific. Methylsulfuric acid potassium salt was purchased from Acros Organics. Neurobiotin tracer was purchased from Vector Laboratories.

Data analysis. All values reported are mean \pm SEM. All statistics were computed using Prism 6.0 software. Two-tailed Student's $t$ tests and two-way ANOVAs were used to analyze data, using repeated-measures designs wherever feasible. The nonparametric Kolmogorov-Smirnov test was used to compare cumulative distributions in situations where two groups being compared had unequal variances or were not normally distributed. Linear regression was used to analyze the relationship be- 
A

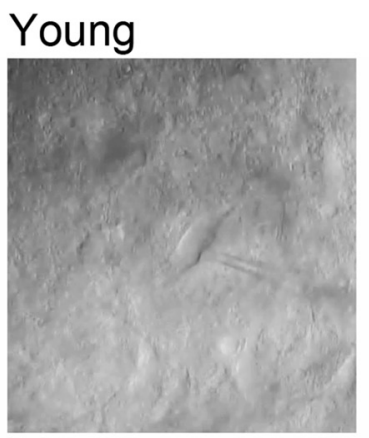

Old

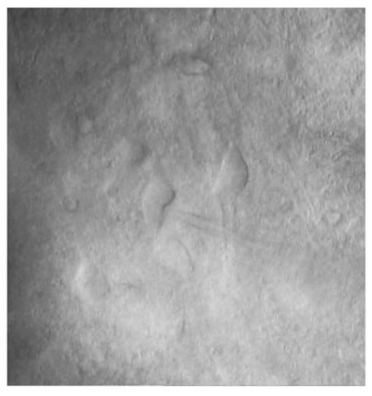

\section{Old}

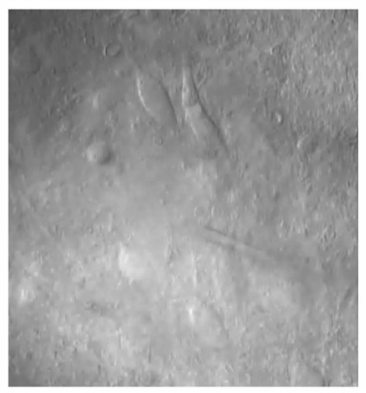

B

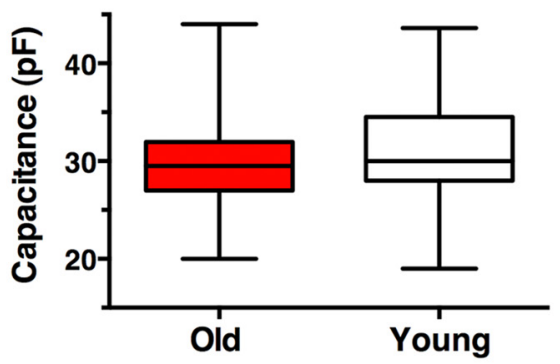

D

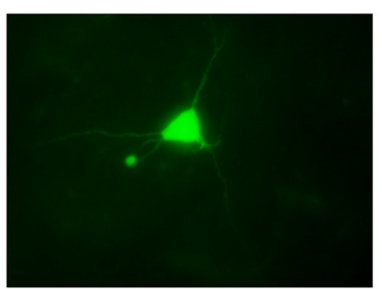

Neurobiotin

E

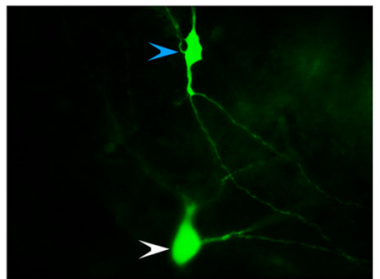

Neurobiotin

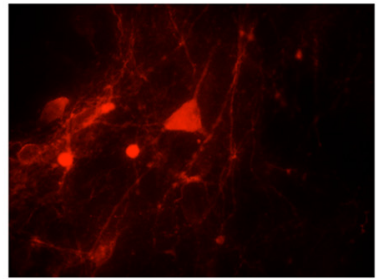

TH

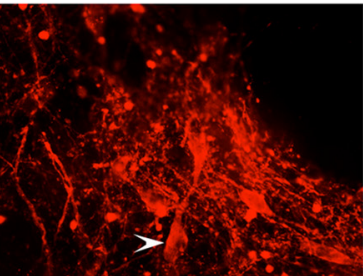

$\mathrm{TH}$
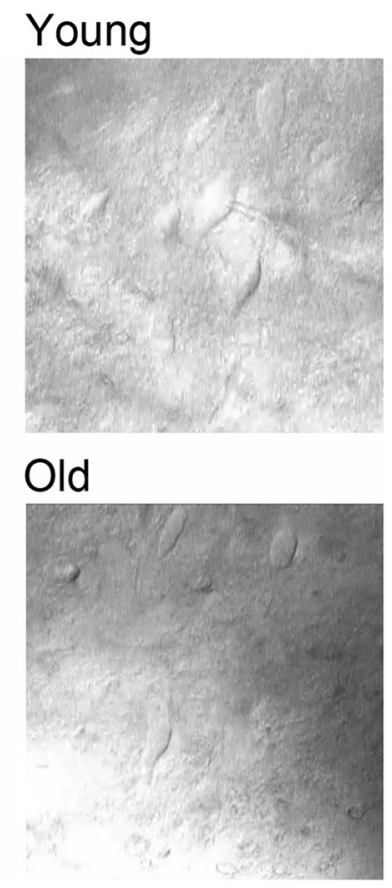

Old

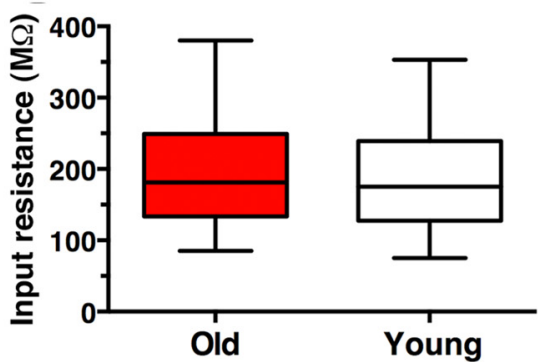

Old

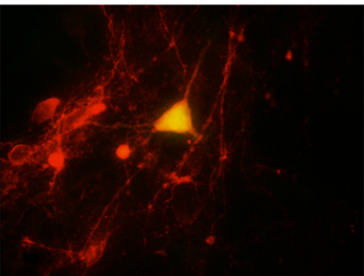

Merge

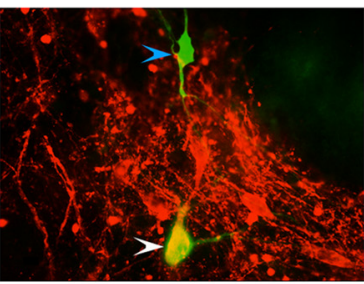

Merge
Figure 1. DA neurons from aging mice maintain their appearance and basal electrophysiological parameters. Mouse brain slices from old and young mice were examined with an upright microscope using gradient contrast optics, and DA neurons of the substantia nigra pars compacta were initially identified by location and appearance. $\boldsymbol{A}$, Brain slices from old mice (25-30 months) showed visually intact DA neurons similar to young adult (2-7 months) mice. $\boldsymbol{B}$, Cell membrane capacitance was measured and was not different in neurons from old mice compared with their young counterparts. $\boldsymbol{C}$, Input resistance was also similar in DA tween mouse age (in weeks) and nimodipinesensitive currents. For all analyses, $\alpha$ was set $a$ priori at 0.05 .

\section{Results}

To maximize the quality and health of the neurons in our brain slice preparation, we deeply anesthetized mice with 2,2,2tribromoethanol (300-500 $\mathrm{mg} / \mathrm{kg}$, i.p.) and transcardially perfused the mice for $60 \mathrm{~s}$ with ice-cold aCSF that included the glutamate receptor antagonist kynurenic acid (1.25 mM). We then rapidly removed the brain and isolated horizontal slices of the ventral mesencephalon containing the substantia nigra. Visualization of DA neurons in slices from young adult (2-7 months) and very old (25-30 months) mice was accomplished using gradient contrast infrared optics (Dodt et al., 2002) and is depicted in Figure $1 A$. Although, in general, the number of visibly healthy neurons was lower in preparations from older mice, intact DA neurons with characteristic large cell bodies were visible in every preparation near the medial terminal nucleus of the accessory optic tract, regardless of the age of the mouse. Surprisingly, wholecell recordings made in these neurons indicated that neither membrane capacitance (Kolmogorov-Smirnov test, $p=$ $0.31)$ nor input resistance $\left(t_{(84)}=0.6658\right.$, $p=0.51)$ significantly differed between age groups (old: $29.78 \pm 0.67 \mathrm{pF}, 191.9 \pm$ $11.6 \mathrm{M} \Omega, n=41$; young: $30.98 \pm 0.88 \mathrm{pF}$, $181.5 \pm 10.4 \mathrm{M} \Omega, n=45$; Fig. $1 B, C)$. In a subset of recordings, neurons were filled with $0.2 \%$ neurobiotin tracer, which was included in the internal solution of the recording pipette. After recordings, slices were preserved in 4\% PFA and later stained for neurobiotin and for tyrosine hydroxylase $(\mathrm{TH})$ to confirm their identity as dopamine neurons (Fig. $1 D ; n=$ 23). Because of the duration of our experiments, which often exceeded $40 \mathrm{~min}$, dual staining was not observed in 10 of 33 cases. In each of these cases, an adjacent cell had also been patch-clamped for

$\leftarrow$

neurons from old and young mice. Boxplot whiskers indicate maximum and minimum data points. $\boldsymbol{D}$, In a subset of experiments, $0.2 \%$ neurobiotin was included in the intracellular solution and slices were fixed with PFA for immunohistochemistry; $70 \%$ of neurons costained for neurobiotin and $\mathrm{TH}$, an indicator of catecholaminergic neurons. When whole-cell patch-clamp experiments exceeded 15 min, a nearby neuron was also briefly patch-clamped to account for the fact that false negatives occur when TH staining is attempted after long recordings ( $\boldsymbol{E}$, blue arrowheads) (Zhang et al., 2010); and in 9 of 10 remaining cases, the nearby neuron dual-stained for neurobiotin and $T H$ ( $\boldsymbol{E}$, white arrowheads). 
A

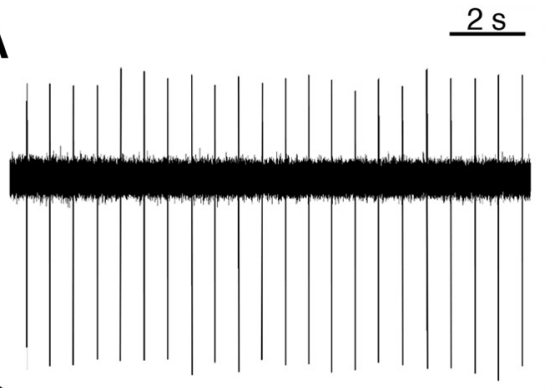

C


B

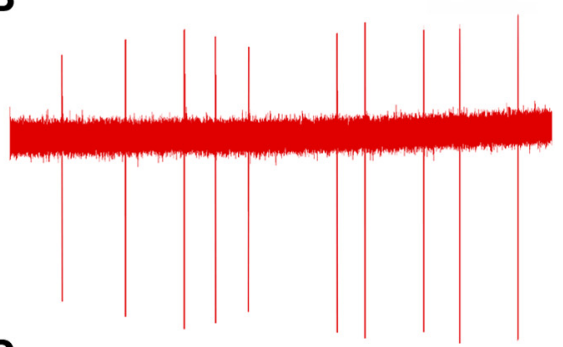

D



$\mathbf{F}$

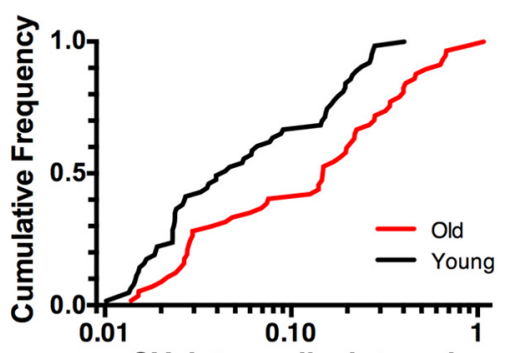

H

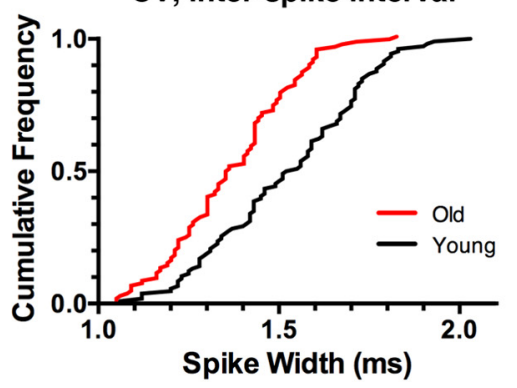

Figure 2. Pacemaker firing fidelity is compromised in DA neurons from aging mice. Intrinsic firing of substantia nigra DA neurons was monitored using loose cell attached extracellular recordings. $A$, The majority of DA neurons from young mice fired in a characteristic rhythmic pattern. $\boldsymbol{B}$, In contrast, DA neurons from old mice (in red) often exhibited more varied firing that, in extreme cases, included gaps of several seconds with no spikes. $\boldsymbol{C}, \boldsymbol{D}, 0$ verall firing rates of neurons from old mice were slower than their young counterparts. Interspike intervals were calculated over 30 s of firing, and neurons from old mice exhibited significantly larger coefficients of variation of the interspike interval compared with neurons from young mice, indicative of a more variable firing pattern $(\boldsymbol{E})$. $\boldsymbol{F}$, Cumulative frequency analysis revealed a bimodal distribution for the coefficient of variation, with values $<0.10$ generally indicative of pacemaker firing. $\mathbf{G}, \boldsymbol{H}$, The kinetics of the extracellular waveforms were also analyzed and indicated that DA neurons from old mice exhibit narrower spike widths compared with their young counterparts. ${ }^{*} p<0.05 .{ }^{* *} p<0.01$. **** $p<0.0001$.

$30-60 \mathrm{~s}$, which is sufficiently short to prevent "washout" of TH signal that is associated with recordings longer than $15 \mathrm{~min}$ (Zhang et al., 2010). In these cases, the nearby cell was dualstained in 9 of 10 cases (Fig. $1 E ; n=9$ ), TH-positive cells were observed nearby, and in only one instance of 33 was the neuron $\mathrm{TH}$ - and neurobiotin-negative due to either poor slice handling and/or imaging. This indicates that DA neurons from aging mice not only maintain their appearance but also basal parameters, including their cell size and composite membrane conductance.
Substantia nigra DA neurons fire in a rhythmic pacemaker-like pattern in ex vivo brain slice preparations (Grace and Onn, 1989). We thus obtained loose cellattached recordings of DA neurons to evaluate the effects of aging on pacemaker firing. Most neurons from young mice fired spikes in a characteristic rhythmic pattern (Fig. 2A). However, DA neurons from aging mice were much more likely to exhibit a disrupted spontaneous firing pattern (Fig. 2B). Mean firing rates were significantly slower in neurons from old mice $(1.72 \pm 0.12, n=56)$ compared with young mice $\left(2.18 \pm 0.11, n=66, t_{(120)}=\right.$ $2.831, p=0.0054$; Fig. $2 C, D$ ). Spontaneous firing was recorded for $30 \mathrm{~s}$, and the interspike intervals (i.e., the time between spikes) were calculated for all neurons that fired more than two action potentials during that period. The coefficient of variation of the interspike interval was significantly higher in DA neurons from old mice $(0.225 \pm 0.031, n=57)$ than from their young counterparts $(0.0936 \pm$ $0.0119, n=63$; Kolmogorov-Smirnov test, $p=0.016$; Fig. $2 E, F)$. A closer evaluation of the extracellular spike waveforms was performed, and spike width was defined (in voltage-clamp mode) as the time from the initiation of the inward current to the peak of the outward current (Ford et al., 2006). Neurons from old mice exhibited a narrower spike width (1.37 \pm $0.016, n=105)$ than those from young mice ( $1.52 \pm 0.020, n=106$; Kolmogorov-Smirnov test, $p<0.0001$; Fig. 2G,H). Therefore, although aging does not affect the appearance or basal electrical properties of DA neurons, it does slow spontaneous firing rates, decrease the fidelity of pacemaker firing, and shorten spike widths.

Spontaneous firing of DA neurons in brain slice preparations is almost exclusively driven by slow intrinsic conductances. Both small-conductance $\mathrm{Ca}^{2+}$-sensitive $\mathrm{K}^{+}$(SK) channels and hyperpolarization-activated HCN channels are major determinants of firing rate (Shepard and Bunney, 1991; Wolfart et al., 2001; Neuhoff et al., 2002). We next used whole-cell recordings to investigate the effects of aging on the function of these channels. SK channels are responsible for a slow afterhyperpolarization current (AHC) in DA neurons. We applied a $55 \mathrm{mV}$ depolarizing voltage step for $100 \mathrm{~ms}$, then measured the AHC as the integral of the apamin-sensitive portion of the outward current to determine the total ionic charge that was passed (Ahn et al., 2010) (Fig. 3A). We observed no difference in AHCs in DA neurons from old $(42.09 \pm 4.46 \mathrm{pA} \times \mathrm{s}, n=22)$ versus young mice $\left(47.32 \pm 5.37 \mathrm{pA} \times \mathrm{s}, n=20 ; t_{(40)}=0.755\right.$, $p=0.45$; Fig. $3 B$ ). We then used a $50 \mathrm{mV}$ hyperpolarizing step to activate the $\mathrm{HCN}$ channel-mediated current $\mathrm{I}_{\mathrm{H}}$, which produces a 
prominent nonselective cation conductance in DA neurons of the substantia nigra (Fig. 3C). There was no difference in mean $\mathrm{I}_{\mathrm{H}}$ current in DA neurons from old (439.6 $\pm 21.2 \mathrm{pA}, n=92)$ versus young mice $\left(456.6 \pm 25.4 \mathrm{pA}, n=88 ; t_{(178)}=\right.$ $0.517, p=0.61$; Fig. $3 D$ ). These results suggest that age-related alterations in dopamine neuron excitability likely cannot be attributed to changes in SK or $\mathrm{HCN}$ channel conductances.

We next examined voltage-gated sodium and calcium channel-mediated currents, both of which are also major contributors to substantia nigra DA neuron excitability (Wilson and Callaway, 2000; Puopolo et al., 2007). To examine their activity at near-threshold voltages, we performed slow $(14 \mathrm{mV} / \mathrm{s})$, depolarizing voltage ramps using a cesium-based pipette solution and extracellular TEA to minimize the contribution of potassium channels (Fig. 4A). We then bath perfused the sodium channel blocker TTX (500 $\mathrm{nM})$ to determine the relative contribution of voltage-gated sodium channels in old and young mice. We observed that TTX-sensitive currents were similar in

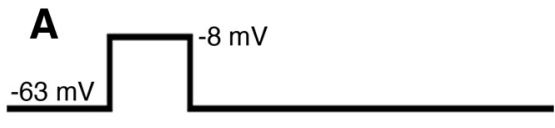

B
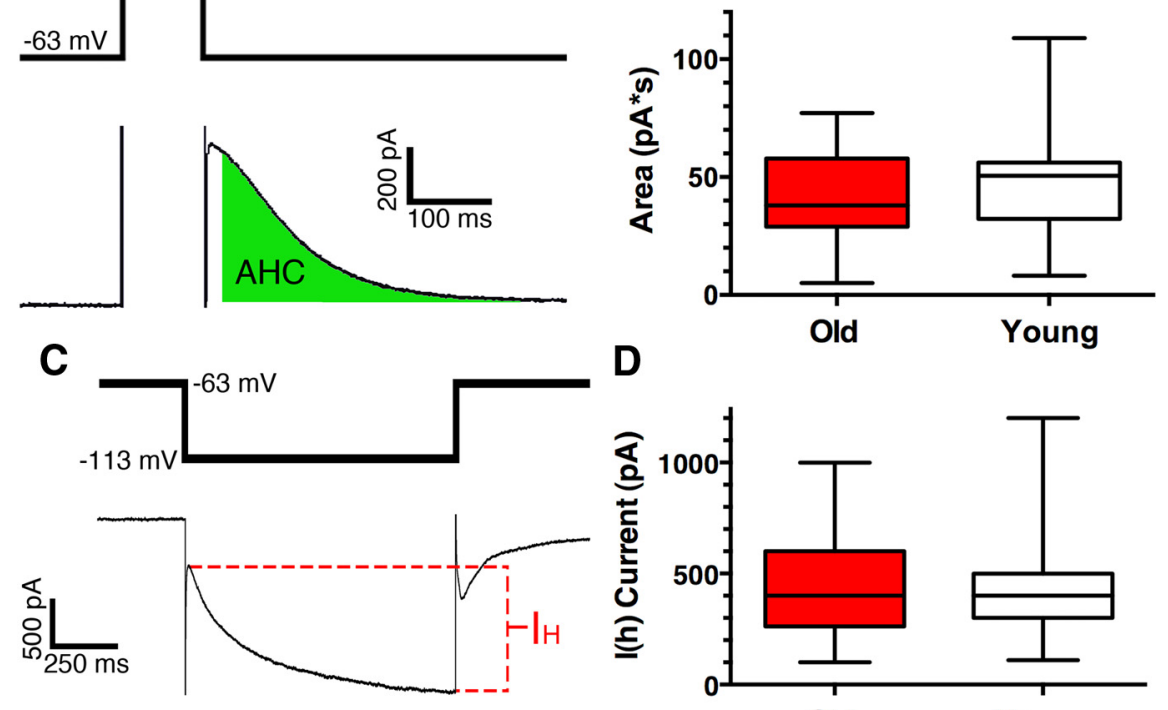

D



Figure 3. Currents associated with $\mathrm{HCN}$ and SK channels are not altered in aging mice. $A$, The AHC, which is primarily mediated by SK channels, was calculated as the area under the curve of the outward current beginning $20 \mathrm{~ms}$ after a $100 \mathrm{~ms}$ depolarization (green shading). B, Summary data indicate that AHCs in DA neurons did not differ with the age of the mice. $C_{,} I_{H}$ currents were calculated as the amplitude of the slow inward current that develops during a $1 \mathrm{~s}$ hyperpolarization step. $\boldsymbol{D}$, Summary data show that $I_{H}$ currents in neurons from old mice were similar to currents in neurons from young mice. Boxplot whiskers indicate maximum and minimum data points.
DA neurons from old and young mice

( $n=12$ and 16 cells, respectively; two-way ANOVA, main effect of age, $F_{(1,26)}=0.1545, p=0.6975$; age $\times$ voltage interaction, $F_{(56,1456)}=0.8148, p=0.8339$; Fig. $\left.4 B\right)$, indicating that agerelated changes in firing patterns are not due to a difference in voltage-gated sodium conductances. With potassium and sodium channels pharmacologically blocked, we next tested the effects of the L-type calcium channel blocker nimodipine ( $3 \mu \mathrm{M})$. At near-threshold voltages, nimodipine significantly attenuated the inward current in neurons from young animals $(n=21$; Fig. $4 C$ ), but summary data indicate that this effect was substantially smaller in neurons from old animals $(n=26$; two-way ANOVA, main effect of age, $F_{(1,45)}=24.1, p<0.0001$; age $\times$ voltage interaction, $F_{(60,2700)}=4.985, p<0.0001$; Fig. $\left.4 D\right)$. Linear regression analysis of individual data points (Fig. $4 E$ ) indicated a significant inverse relationship between the age of the mice in weeks and the maximum amplitude of nimodipine-sensitive inward currents $\left(F_{(1,45)}=11.05, p=0.0018\right)$.

Although calcium influx depolarizes the neuron, it can also activate calcium-sensitive SK channels, causing the extrusion of potassium and slowing firing rate. However, mechanistic changes of voltage-dependent calcium channels due to ages beyond young adulthood have yet to be elucidated. In an attempt to determine the contribution of L-type calcium channels to firing parameters, we obtained extracellular recordings and determined the effect of nimodipine on firing rates in pacemaking DA neurons from old and young mice. Nimodipine initially increased firing rate in neurons from young mice, followed by a slowing of firing. Neurons from old mice fired more slowly after several minutes but lacked the initial increase in firing. Repeatedmeasures ANOVA indicated a significant main effect of age $(n=$ 8 cells/group; $F_{(1,264)}=25.96, p<0.0001$; Fig. $\left.4 F\right)$ and time $\left(F_{(18,264)}=8.562, p<0.0001\right)$ but no significant age $\times$ time interaction $\left(F_{(18,264)}=0.6454, p=0.8618\right)$. We also examined these neurons for nimodipine-induced changes in the coefficient of variation of the interspike interval (Fig. 4G,H). Nimodipine produced an increase in this parameter $\left(F_{(1,19)}=5.436, p=\right.$ $0.03)$, but there was no significant age $X$ nimodipine interaction $\left(F_{(1,19)}=2.828, p=0.11\right)$. One caveat to this finding is that, to perform the experiment in Fig. $4 F$, we could only use neurons in both groups that were stably pacemaking, thus potentially skewing our data toward young-seeming neurons in slices from old mice. Furthermore, many cells in both groups ceased firing altogether during washout (data not shown), possibly indicating slow tissue penetration for nimodipine. Regardless, our data indicate that age diminishes L-type calcium channel-mediated currents in DA neurons and also alters the effect of nimodipine on pacemaker firing. These results suggest that DA neurons from young mice have a larger participation of voltage-gated calcium channels at near-threshold voltages than cells from very old mice.

Finally, we attempted to ascertain whether alterations in ion channel gene expression could be responsible for the age-related decline in physiological parameters. We isolated RNA from the substantia nigra of young and old mice, performed quantitative real time RT-PCR on 10 ion channel genes, and quantified expression by comparing it with the control reference gene eEF $1 \alpha 1$ (Sharma et al., 2010). These analyses revealed no significant agerelated changes in gene expression (Table 1). Interestingly, the only two potential trends in these data were for increased expression in old mice of the genes that code for Cav1.2 and Cav1.3. This is in the opposite direction of our functional findings and could suggest an increase in transcription as a compensation for age-related decline in pacemaker firing. A very similar disparity between age-related changes in L-type channel expression and function has been seen in rat hippocampus, where overall Cav1.2 and Cav1.3 channel expression is decreased but channel surface expression is actually increased, matching previously observed increases in channel activity (Núñez-Santana et al., 2014). 



E

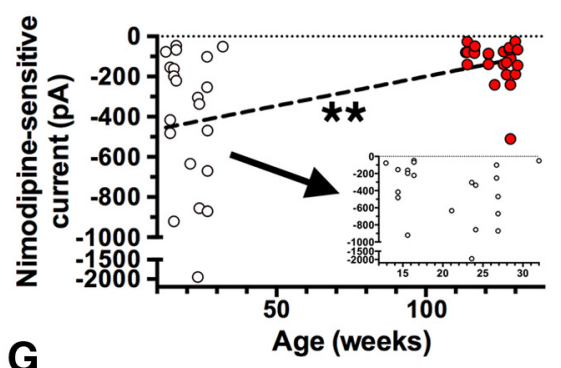

G




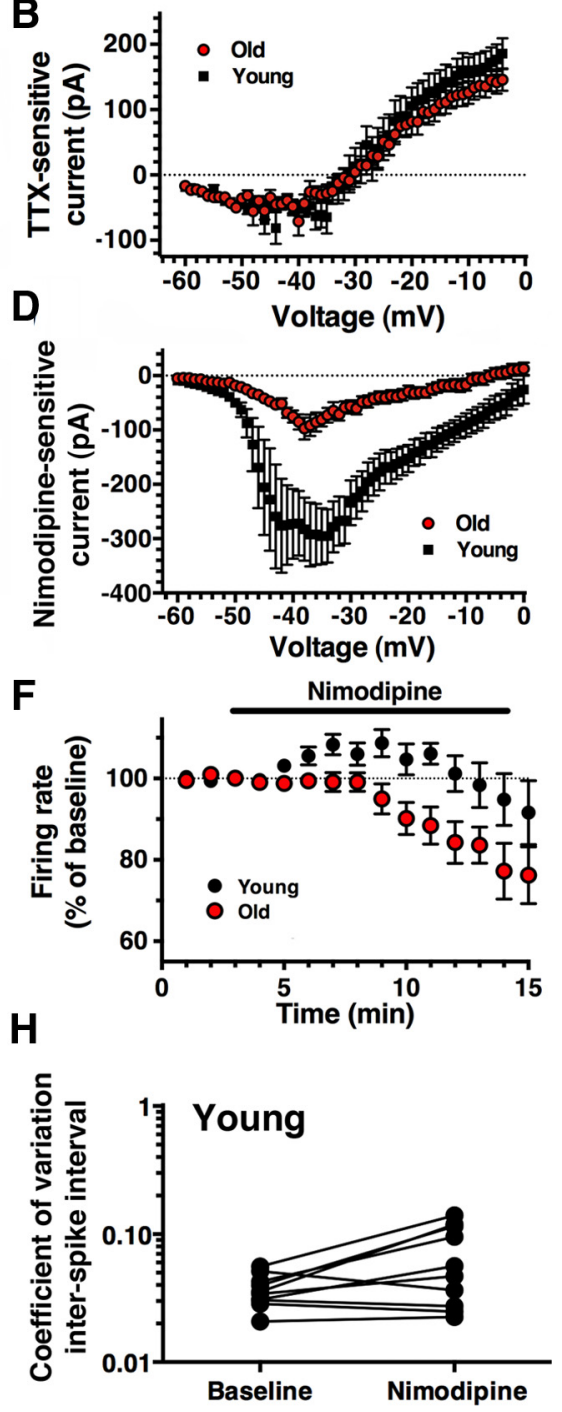

Figure 4. L-type calcium channel-mediated currents are smaller in DA neurons from aging mice. $\boldsymbol{A}$, Using a cesium-based intracellular solution, whole-cell patch-clamp recordings of DA neurons were obtained and slow depolarizing voltage ramps were applied over 10 s. $\boldsymbol{B}$, Currents subtracted after bath perfusion of TTX indicated that there was no effect of age on voltage-gated sodium channel-mediated currents. C, Two sample traces of DA neurons from young mice illustrate a nimodipine-sensitive inward current. A subset of cells exhibited brief inward current deflections in the presence of TTX that were not blocked by nimodipine (e.g., bottom trace). $\boldsymbol{D}$, Summarized data indicate a dramatic decrease in the amplitude of near-threshold nimodipine-sensitive inward currents in neurons from old versus young mice. $\boldsymbol{E}$, Linear regression analysis indicated a significant inverse relationship between the age of the mouse and the maximum nimodipine-sensitive currents (dashed line; $p=0.0018$ ). Linear regression analysis of only the data points from young mice indicated no significant difference in the nimodipine-sensitive currents within that subset of ages (inset, $\left.F_{(1,19)}=0.87, p=0.36\right)$. Using the cell attached method, firing rates of neurons from old and young mice were examined before and after bath application of $3 \mu \mathrm{m}$ nimodipine. $\boldsymbol{F}$, Summarized data indicate a differential effect of nimodipine on firing rate in DA neurons from old and young mice $(p<0.0001)$. Pacemaking neurons from both old $(\boldsymbol{G})$ and young $(\boldsymbol{H})$ mice exhibited similar nimodipine-induced increases in the coefficient of variation of their interspike intervals.

\section{Discussion}

Here we show that DA neurons from old mice exhibit slower firing rates, impaired firing fidelity, shorter spike widths, and decreased L-type calcium currents compared with their young counterparts. We did not observe an effect of age on other electrophysiologically measured parameters, including cell size, input resistance, $\mathrm{I}_{\mathrm{H}}$, and SK channel currents. These findings extend our knowledge of the effects of aging on DA neuron physiology to very old time points at which neurological diseases and bradykinesia are common. This information could prove invaluable for developing pharmacological strategies to treat age-

associated brain disorders affecting the dopaminergic system. Further, because dihydropyridines have been proposed as a potential treatment for PD, our results could suggest a limited temporal window for the efficacy of this therapeutic intervention.

\section{Intrinsic ion conductances and dopamine neuron firing}

DA neurons are autonomous pacemakers that fire action potentials even in the absence of active excitatory synaptic input. In vivo, tonic firing of substantia nigra dopamine neurons promotes DA release in the dorsal striatum that is critical for the initiation of voluntary movement (Carli et al., 1985; Tepper et al., 1991). In ex vivo brain slice preparations, such as the one used presently, DA neurons typically fire in a rhythmic, pacemaker-like pattern (Grace and Onn, 1989). DA neuron pacemaking is influenced by intrinsic ion conductances, and the role of voltagedependent calcium channels on this firing has been studied in a variety of preparations. Previous work suggests that L-type calcium currents are heavily involved in control of spontaneous firing frequency, specifically by inducing a near-threshold depolarization and a subsequent activation of an SK channel-mediated afterhyperpolarization potential (Puopolo et al., 2007). Although L-type calcium currents are generally considered to be highvoltage activated, L-type currents in substantia nigra DA neurons are largely mediated by $\mathrm{Ca}_{\mathrm{V}} 1.3$ channel subunits (Takada et al., 2001), which activate at relatively negative potentials and inactivate slowly (Kang and Kitai, 1993; Wilson and Callaway, 2000). These channels drive pacemaker firing by producing slow voltage oscillations in both somatic and dendritic compartments (Grace, 1991; Kang and Kitai, 1993; Wilson and Callaway, 2000). Because pacemaker firing in the substantia nigra is dependent on nearthreshold calcium currents, a decrease in channel density alone could disrupt the coupling between the dendrites and the soma and decrease firing regularity (Wilson and Callaway, 2000). The dramatically decreased nimodipinesensitive currents that we observed in DA neurons from older mice thus likely contributes to the decreased fidelity in pacemaker firing. However, nimodipine did increase the coefficient of variation of the interspike interval in neurons from both young and old mice, indicating that age-related adaptations in other ion channels and/or neuronal structure must also be contributing factors. Calcium entering through L-type calcium channels is also a major contributor to the "shoulder" of the action potential depolarization that determines spike width (Puopolo et al., 2007). Thus, the decrease in L-type cur- 
Table 1. Ion channel gene expression in young and old mice ${ }^{a}$

\begin{tabular}{lllll}
\hline Gene & Subunit & Old & Young & $p$ \\
\hline Scn1a & Nav1.1 & $2.21 \pm 0.24(5)$ & $2.17 \pm 0.28(7)$ & 0.91 \\
Scn2a & Nav1.2 & $0.88 \pm 0.29(4)$ & $0.84 \pm 0.17(7)$ & 0.91 \\
Scn5a & Nav1.5 & $0.15 \pm 0.05(4)$ & $0.16 \pm 0.03(7)$ & 0.96 \\
Scn1b & NavB1 & $0.89 \pm 0.17(4)$ & $0.89 \pm 0.05(7)$ & 0.99 \\
Scn2b & NavB2 & $1.23 \pm 0.26(4)$ & $1.34 \pm 0.13(7)$ & 0.69 \\
Scn3b & NavB3 & $1.28 \pm 0.18(4)$ & $1.24 \pm 0.08(7)$ & 0.82 \\
Hen1 & HCN1 & $2.12 \pm 0.44(4)$ & $1.85 \pm 0.36(7)$ & 0.65 \\
Kcnn3 & SK3 & $0.24 \pm 0.05(4)$ & $0.24 \pm 0.03(7)$ & 0.97 \\
Cacna1c & Cav1.2 & $1.32 \pm 0.33(5)$ & $0.96 \pm 0.13(7)$ & 0.29 \\
Cacna1d & Cav1.3 & $1.10 \pm 0.22(5)$ & $0.78 \pm 0.21(7)$ & 0.15 \\
\hline
\end{tabular}

${ }^{a}$ We performed real-time qRT-PCR on substantia nigra samples taken from young and old mice. Values are mean \pm SEM of the ratio of each gene's expression in relation to the control reference gene eEF1 $\alpha 1$, with sample size in parentheses. $p$ values were obtained from two-tailed, unpaired $t$ tests.

rents is consistent with the decreased spike width we observed in neurons from aging mice.

One important caveat is that, in addition to blocking $\mathrm{Ca}_{\mathrm{V}} 1.2$ and 1.3, $3 \mu \mathrm{M}$ nimodipine can partially block some T-type calcium channels $\left(\mathrm{Ca}_{\mathrm{V}} 3.2\right.$ or 3.3) (Furukawa et al., 2009). T-type channel-mediated currents have been observed in substantia nigra dopamine neurons from very young rodents and can either contribute to irregular firing (in P6-P12 rats) (Cui et al., 2004) or, in some neurons from $\mathrm{P} 10-\mathrm{P} 14$ mice, pacemaker regularity by activating SK channels (Wolfart and Roeper, 2002). Although we cannot currently rule out a role for T-type channels in the agerelated effects of DA neuron physiology, our experimental protocols suggest that they are not responsible for the observed effects of nimodipine. We used extremely slow ramp protocols $(14 \mathrm{mV} / \mathrm{s})$ that limit the contribution of rapidly inactivating channels, such as T-type calcium channels. Furthermore, T-type activation occurs at low voltages and in DA neurons inactivates at $-40 \mathrm{mV}$ (Cui et al., 2004), suggesting that T-type channels are not central to the effects of nimodipine that peak positive of -40 $\mathrm{mV}$. Although we did not study them in detail, the brief inward currents we observed in some cells (e.g., Fig. 4C, bottom) could have been the result of T-type channels and were not blocked by nimodipine. Finally, tissue penetration issues often necessitate perfusion of higher concentrations of antagonists in brain slices over cellular preparations (such as the Furukawa et al. 2009 study, which was performed in Xenopus oocytes) to produce the same effects. We believe this to be important in the present study due to the following: (1) because of the difficulty of recording from old mice, we intentionally recorded from deep cells in both groups to maximize neuronal health; (2) bath perfusion of $300 \mathrm{~nm}$ nimodipine (which should have blocked $\mathrm{Ca}_{\mathrm{V}} 1.2$ and 1.3) had very little effect on firing rate, firing fidelity, and ramp-induced currents (data not shown); and (3) $3 \mu \mathrm{M}$ nimodipine caused firing to completely cease in many neurons from both groups during washout, suggesting that the drug was still penetrating the slice tissue. More work will be required to address this complex issue as more selective blockers of L- and T-type channel subunits become available. It is perhaps noteworthy that microdialysis data do not support a role for T-type channels in the somatodendritic release of dopamine in the substantia nigra (Bergquist and Nissbrandt, 2003).

A number of dopamine-mediated behaviors decline with age, including voluntary movement, cognition, and attention (Gerhardt et al., 2002; Nieoullon, 2002; Colebrooke et al., 2006; Gispert et al., 2009). Wholesale death of DA neurons during normal aging could explain these observations, but its actual prevalence is controversial (Kubis et al., 2000; Haycock et al., 2003). If
DA neuron death does occur with normal aging, it is only in the range of $10 \%-30 \%$ and alone is unlikely to explain the neurochemical and behavior deficits observed with advancing age (McGeer et al., 1977; Bäckman and Farde, 2001). Neurochemical experiments suggest that extracellular levels of DA decrease with age, perhaps by $60 \%$ in the striatum, despite an apparent decrease in DA uptake (Hebert and Gerhardt, 1998; Gerhardt et al., 2002; Haycock et al., 2003; Colebrooke et al., 2006). This suggests that, during aging, at least a portion of the surviving DA neurons develop changes in their physiology that produce a degree of functional senescence. An age-related decrease in the DA synthesizing enzyme dopa decarboxylase could contribute to this effect (CruzMuros et al., 2007). Our results suggest that the decreasing amplitude of the L-type calcium currents that contribute to DA neuron firing could play a role in age-related decrements in dopamine-mediated signaling and its behavioral consequences.

\section{L-type calcium channels and dopamine neuron degeneration}

The reliance on subthreshold calcium currents for pacemaker firing could explain why DA neurons in the substantia nigra are susceptible to the significant neurodegeneration required for the appearance of motor symptoms in PD (Hornykiewicz, 1975; McGeer et al., 1988; Khaliq and Bean, 2010). Increased intracellular calcium can stress the organelles responsible for maintaining calcium homeostasis and has been linked to apoptosis and the formation of reactive oxygen species (Orrenius et al., 2003). This, combined with the fact that these neurons have only a modest ability to buffer calcium (Foehring et al., 2009), suggests that any insult that increases the cytoplasmic calcium burden could expose the cells to calcium-dependent pathology. It has thus been proposed that dihydropyridines, such as nimodipine and isradipine, already in use as therapeutic agents to treat hypertension, could also protect patients from the neurodegeneration that is characteristic of PD and other age-related neuronal phenotypes. Consistent with this notion, calcium-channel blocker usage in humans decreases the chance of being diagnosed with PD (Becker et al., 2008), and isradipine administration reduces oxidative damage to DA neurons in a mouse model of PD (Ilijic et al., 2011).

The present study identified alterations in DA neuron physiology associated with normal aging and did not investigate a model of PD. However, because aging is the leading risk factor for the development of PD, our results could have important implications for the treatment of PD patients. The decline in L-type calcium currents we observed in neurons from aging (yet visually healthy) animals suggests that there may be a limited time window for treatment with L-type antagonists, likely before overt motor impairments are evident. It is also conceivable that the age-related alterations we observed in dopamine neuron physiology are part of an adaptive process designed to extend the lifespan of individual neurons by reducing L-type calcium currents, sacrificing firing fidelity in the process. Fortunately, the late onset of motor symptoms in PD suggests a relatively slow time course for DA neuron degeneration. An ideal therapeutic regimen for PD would combine symptomatic treatment with a neurorestorative intervention to protect or enhance the function of remaining neurons (Dawson and Dawson, 2002). Thus, it is key that we continue to identify adaptive changes that occur with aging and during the early stages of PD to establish improved drug therapies to halt, slow, or reverse neurodegeneration. Additionally, a carefully constructed time course of the degenerative changes occurring during disease development will be required to best determine effective therapeutic interventions. 


\section{References}

Ahn KC, Bernier BE, Harnett MT, Morikawa H (2010) IP3 receptor sensitization during in vivo amphetamine experience enhances NMDA receptor plasticity in DA neurons of the ventral tegmental area. J Neurosci 30:6689-6699. CrossRef Medline

Bäckman L, Farde L (2001) DA and cognitive functioning: brain imaging findings in Huntington's disease and normal aging. Scand J Psychol 42: 287-296. CrossRef Medline

Becker C, Jick SS, Meier CR (2008) Use of antihypertensives and the risk of Parkinson disease. Neurology 70:1438-1444. CrossRef Medline

Bergquist F, Nissbrandt H (2003) Influence of R-type (Cav2.3) and t-type (Cav3.1-3.3) antagonists on nigral somatodendritic dopamine release measured by microdialysis. Neuroscience 120:757-764. CrossRef Medline

Branch SY, Beckstead MJ (2012) Methamphetamine produces bidirectional, concentration-dependent effects on DA neuron excitability and dopamine-mediated synaptic currents. J Neurophysiol 108:802-809. CrossRef Medline

Carli M, Evenden JL, Robbins TW (1985) Depletion of unilateral striatal DA impairs initiation of contralateral actions and not sensory attention. Nature 313:679-682. CrossRef Medline

Chan CS, Guzman JN, Ilijic E, Mercer JN, Rick C, Tkatch T, Meredith GE, Surmeier DJ (2007) 'Rejuvenation' protects neurons in mouse models of Parkinson's disease. Nature 447:1081-1086. CrossRef Medline

Chen BT, Bowers MS, Martin M, Hopf FW, Guillory AM, Carelli RM, Chou JK, Bonci A (2008) Cocaine but not natural reward self-administration nor passive cocaine infusion produces persistent LTP in the VTA. Neuron 59:288-297. CrossRef Medline

Colebrooke RE, Humby T, Lynch PJ, McGowan DP, Xia J, Emson PC (2006) Age-related decline in striatal DA content and motor performance occurs in the absence of nigral cell loss in a genetic mouse model of Parkinson's disease. Eur J Neurosci 24:2622-2630. CrossRef Medline

Cruz-Muros I, Afonso-Oramas D, Abreu P, Barroso-Chinea P, Rodríguez M, González MC, Hernández TG (2007) Aging of the rat mesostriatal system: differences between the nigrostriatal and the mesolimbic compartments. Exp Neurol 204:147-161. CrossRef Medline

Cui G, Okamoto T, Morikawa H (2004) Spontaneous opening of T-type $\mathrm{Ca}^{2+}$ channels contributes to the irregular firing of dopamine neurons in neonatal rats. J Neurosci 24:11079-11087. CrossRef Medline

Dawson TM, Dawson VL (2002) Neuroprotective and neurorestorative strategies for Parkinson's disease. Nat Neurosci 5 [Suppl]:1058-1061. CrossRef Medline

Dodt HU, Eder M, Schierloh A, Zieglgänsberger W (2002) Infrared-guided laser stimulation of neurons in brain slices. Sci STKE 2002:pl2. CrossRef Medline

Dryanovski DI, Guzman JN, Xie Z, Galteri DJ, Volpicelli-Daley LA, Lee VM, Miller RJ, Schumacker PT, Surmeier DJ (2013) Calcium entry and $\alpha$-synuclein inclusions elevate dendritic mitochondrial oxidant stress in dopaminergic neurons. J Neurosci 33:10154-10164. CrossRef Medline

Foehring RC, Zhang XF, Lee JC, Callaway JC (2009) Endogenous calcium buffering capacity of substantia nigral dopamine neurons. J Neurophysiol 102:2326-2333. CrossRef Medline

Ford CP, Mark GP, Williams JT (2006) Properties and opioid inhibition of mesolimbic DA neurons vary according to target location. J Neurosci 26:2788-2797. CrossRef Medline

Furukawa T, Nukada T, Namiki Y, Miyashita Y, Hatsuno K, Ueno Y, Yamakawa T, Isshiki T (2009) Five different profiles of dihydropyridines in blocking T-type $\mathrm{Ca}(2+)$ channel subtypes $(\mathrm{Ca}(\mathrm{v}) 3.1$ (alpha( $(\mathrm{G})$ ), $\mathrm{Ca}(\mathrm{v}) 3.2(\mathrm{alpha}(1 \mathrm{H})$ ), and $\mathrm{Ca}(\mathrm{v}) 3.3$ (alpha(1I)) expressed in Xenopus oocytes. Eur J Pharmacol 613:100-107. CrossRef Medline

Gerhardt GA, Cass WA, Yi A, Zhang Z, Gash DM (2002) Changes in somatodendritic but not terminal DA regulation in aged rhesus monkeys. J Neurochem 80:168-177. CrossRef Medline

Gispert S, Ricciardi F, Kurz A, Azizov M, Hoepken HH, Becker D, Voos W, Leuner K, Müller WE, Kudin AP, Kunz WS, Zimmermann A, Roeper J, Wenzel D, Jendrach M, García-Arencíbia M, Fernández-Ruiz J, Huber L, Rohrer H, Barrera M, et al. (2009) Parkinson phenotype in aged PINK1deficient mice is accompanied by progressive mitochondrial dysfunction in absence of neurodegeneration. PLoS One 4:e5777. CrossRef Medline

Grace AA (1991) Regulation of spontaneous activity and oscillatory spike firing in rat midbrain DA neurons recorded in vitro. Synapse 7:221-234. CrossRef Medline
Grace AA, Onn SP (1989) Morphology and electrophysiological properties of immunocytochemically identified rat DA neurons recorded in vitro. J Neurosci 9:3463-3481. Medline

Guzman JN, Sanchez-Padilla J, Wokosin D, Kondapalli J, Ilijic E, Schumacker PT, Surmeier DJ (2010) Oxidant stress evoked by pacemaking in dopaminergic neurons is attenuated by DJ-1. Nature 468:696-700. CrossRef Medline

Hahn J, Tse TE, Levitan ES (2003) Long-term $\mathrm{K}^{+}$channel-mediated dampening of dopamine neuron excitability by the antipsychotic drug haloperidol. J Neurosci 23:10859-10866. Medline

Hahn J, Kullmann PH, Horn JP, Levitan ES (2006) D2 autoreceptors chronically enhance dopamine neuron pacemaker activity. J Neurosci 26:5240 5247. CrossRef Medline

Haycock JW, Becker L, Ang L, Furukawa Y, Hornykiewicz O, Kish SJ (2003) Marked disparity between age-related changes in DA and other presynaptic dopaminergic markers in human striatum. J Neurochem 87:574585. CrossRef Medline

Hebert MA, Gerhardt GA (1998) Normal and drug-induced locomotor behavior in aging: comparison to evoked DA release and tissue content in Fischer 344 rats. Brain Res 797:42-54. CrossRef Medline

Hnasko TS, Perez FA, Scouras AD, Stoll EA, Gale SD, Luquet S, Phillips PE, Kremer EJ, Palmiter RD (2006) Cre recombinase-mediated restoration of nigrostriatal DA in dopamine-deficient mice reverses hypophagia and bradykinesia. Proc Natl Acad Sci U S A 103:8858-8863. CrossRef Medline

Hornykiewicz O (1975) Parkinson's disease and its chemotherapy. Biochem Pharmacol 24:1061-1065. CrossRef Medline

Ilijic E, Guzman JN, Surmeier DJ (2011) The L-type channel antagonist isradipine is neuroprotective in a mouse model of Parkinson's disease. Neurobiol Dis 43:364-371. CrossRef Medline

Jin X, Costa RM (2010) Start/stop signals emerge in nigrostriatal circuits during sequence learning. Nature 466:457-462. CrossRef Medline

Kang Y, Kitai ST (1993) Calcium spike underlying rhythmic firing in dopaminergic neurons of the rat substantia nigra. Neurosci Res 18:195-207. CrossRef Medline

Khaliq ZM, Bean BP (2008) Dynamic, nonlinear feedback regulation of slow pacemaking by A-type potassium current in ventral tegmental area neurons. J Neurosci 28:10905-10917. CrossRef Medline

Khaliq ZM, Bean BP (2010) Pacemaking in dopaminergic ventral tegmental area neurons: depolarizing drive from background and voltagedependent sodium conductances. J Neurosci 30:7401-7413. CrossRef Medline

Kubis N, Faucheux BA, Ransmayr G, Damier P, Duyckaerts C, Henin D, Forette B, Le Charpentier Y, Hauw JJ, Agid Y, Hirsch EC (2000) Preservation of midbrain catecholaminergic neurons in very old human subjects. Brain 123:366-373. CrossRef Medline

Liss B, Franz O, Sewing S, Bruns R, Neuhoff H, Roeper J (2001) Tuning pacemaker frequency of individual dopaminergic neurons by $\mathrm{Kv} 4.3 \mathrm{~L}$ and KChip3.1 transcription. EMBO J 20:5715-5724. CrossRef Medline

McGeer PL, McGeer EG, Suzuki JS (1977) Aging and extrapyramidal function. Arch Neurol 34:33-35. CrossRef Medline

McGeer PL, Itagaki S, Akiyama H, McGeer EG (1988) Rate of cell death in parkinsonism indicates active neuropathological process. Ann Neurol 24: 574-576. CrossRef Medline

Neher E (1992) Correction for liquid junction potentials in patch clamp experiments. Methods Enzymol 207:123-131. CrossRef Medline

Neuhoff H, Neu A, Liss B, Roeper J (2002) I(h) channels contribute to the different functional properties of identified dopaminergic subpopulations in the midbrain. J Neurosci 22:1290-1302. Medline

Nieoullon A (2002) Dopamine and the regulation of cognition and attention. Prog Neurobiol 67:53-83. CrossRef Medline

Núñez-Santana FL, Oh MM, Antion MD, Lee A, Hell JW, Disterhoft JF (2014) Surface L-type $\mathrm{Ca}^{2+}$ channel expression levels are increased in aged hippocampus. Aging Cell 13:111-120. CrossRef Medline

Orrenius S, Zhivotovsky B, Nicotera P (2003) Regulation of cell death: the calcium-apoptosis link. Nat Rev Mol Cell Biol 4:552-565. CrossRef Medline

Pfaffl MW, Horgan GW, Dempfle L (2002) Relative expression software tool (REST) for group-wise comparison and statistical analysis of relative expression results in real-time PCR. Nucleic Acids Res 30:e36. CrossRef Medline

Puopolo M, Raviola E, Bean BP (2007) Roles of sub threshold calcium cur- 
rent and sodium current in spontaneous firing of mouse midbrain DA neurons. J Neurosci 27:645-656. CrossRef Medline

Putzier I, Kullmann PH, Horn JP, Levitan ES (2009) Cav1.3 channel voltage dependence, not $\mathrm{Ca}^{2+}$ selectivity, drives pacemaker activity and amplifies bursts in nigral DA neurons. J Neurosci 29:15414-15419. CrossRef Medline

Sharma R, Tsuchiya M, Skobe Z, Tannous BA, Bartlett JD (2010) The acid test of fluoride: how pH modulates toxicity. PLoS One 5:e10895. CrossRef Medline

Shepard PD, Bunney BS (1991) Repetitive firing properties of putative DA containing neurons in vitro: regulation by an apamin sensitive Ca activated $\mathrm{K}$ conductance. Exp Brain Res 86:141-150. Medline

Surmeier DJ, Mercer JN, Chan CS (2005) Autonomous pacemakers in the basal ganglia: who needs excitatory synapses anyway? Curr Opin Neurobiol 15:312-318. CrossRef Medline

Takada M, Kang Y, Imanishi M (2001) Immunohistochemical localization of voltage-gated calcium channels in substantia nigra dopamine neurons. Eur J Neurosci 13:757-762. CrossRef Medline
Tepper JM, Creese I, Schwartz DH (1991) Stimulus-evoked changes in neostriatal DA levels in awake and anesthetized rats as measured by microdialysis. Brain Res 559:283-292. CrossRef Medline

Wilson CJ, Callaway JC (2000) Coupled oscillator model of the dopaminergic neuron of the substantia nigra. J Neurophysiol 83:3084-3100. Medline

Wolfart J, Roeper J (2002) Selective coupling of T-type calcium channels to SK potassium channels prevents intrinsic bursting in dopaminergic midbrain neurons. J Neurosci 22:3404-3413. Medline

Wolfart J, Neuhoff H, Franz O, Roeper J (2001) Differential expression of the small-conductance, calcium-activated potassium channel SK3 is critical for pacemaker control in dopaminergic midbrain neurons. J Neurosci 21:3443-3456. Medline

Zhang TA, Placzek AN, Dani JA (2010) In vitro identification and electrophysiological characterization of dopamine neurons in the ventral tegmental area. Neuropharmacology 59:431-436. CrossRef Medline 